\title{
THE ADMINISTATION OF CRIMINAL LAW IN SCOTLAND.
}

Although the crowns of England and Scotland have been united for three centuries and their Parliaments for two, the system of criminal administration in Scotland is still distinctively national. Indeed, with the exception of the National Church, in its constitution and government, there is, perhaps, no other Scottish institution which bears less trace of English influence. The action of the legislature, the position of the House of Lords, as a common appellate court in civil matters, the close commercial and social relations between the two countries, and other causes have exercised a certain assimilative influence in some branches of civil law and procedure, but criminal law and procedure have been modified by no extraneous influences, and what changes have been introduced by the legislature have been of purely Scottish origin, and would probably have been passed in a similar form by a Scottish Parliament, having no cognizance of any other system but its own. Scottish pride in what is national has always been tempered by a readiness to adopt valuable suggestions from abroad, but, whether from the inherent excellence of the Scottish system, or from its special suitability to the Scottish people, this virtue has not found opportunity for exemplification in the domain of criminal jurisprudence. Here, indeed, the retentive, rather than the acquisitive side of the Scottish character, has had full scope. There is no institution with which Scotsmen are better satisfied or less disposed to tamper, and no subject on which they are less inclined to believe that they have anything to learn. This is, perhaps, the more remarkable, because whilst the Scottish system has certain admirable features, it contains elements, which to those who are unfamiliar with their working, may appear hardly compatible with personal liberty, which are contrary to some of the most cherished traditions of English criminal law, and the attempt to impose some of which, even in a modified form, :pon Ireland, has been resisted and denounced as intolerable tyranny. 
It is not possible here to do more than to present the barest outline of the Scottish system. All details will, in so far as possible, be avoided. The nature and constitution of the criminal courts will first be explained; then there will be a brief statement in regard to the authority in the hands of which the prosecution of crime is reposed; and finally, the working of the system and some of the salient features of procedure will be explained by tracing in outline the proceedings which take place from the commission of an offence to the conviction and sentence of the offender.

\section{The Criminal Courts.}

The Court of Justiciary. From the dawn of history there was in Scotland, as in other European monarchies, attached to the Court of the King, a great Magistrate or Officer of State, called the Justice or Justiciar of the Kingdom, to whom belonged the supreme cognizance of all causes, civil or criminal, within the realm, and who, in the name of the sovereign, held what was called the King's Court. The King himself sometimes sat as Judge in this Court, and, in the absence of the King and of the Justiciar, Justice Deputes were appointed to act. There appears to have been an appeal to Parliament from the Justiciar's judgments in civil causes, but not in criminal ones. On the institution of the present Court of Session in 1532 , civil jurisdiction was transferred to that Court, with which it has since remained. For some centuries there appear to have been two Justiciars; one for the North and the other for the South of the Forth, but in the reign of Queen Mary the old system of having one Justiciar for the whole Kingdom was reverted to. In 167 I the Court of Justiciary was reconstituted, practically on its present basis, and was to consist of the Justiciar (or Lord Justice General, as he is now called), the Lord Justice Clerk (an office, which like that of Master of the Rolls, in England, had grown from a mere clerkship to high judicial dignity), and five of the Judges of the Court of Session. Under an Act, passed sixty years ago, the offices of Lord Jus'ıce General and Lord President, of the Court of Session, werr conjoined in the same person, and under 
another Act of 1887 , the whole of the Judges of the Court of Session were made Judges of the Justiciary Court. Accordingly, although the two Courts are still distinct and have independent and exclusive jurisdictions, the benches are manned by the same judicial staff, which numbers thirteen judges. The two Courts differ, however, in this important particular, that there is an appeal from the Court of Session to the House of Lords; whilst from the High Court of Justiciary there is no appeal. Its decisions cannot be reviewed or questioned by any authority, judicial or executive. The Court of Justiciary has supreme jurisdiction in all criminal matters; it can try for any criminal offence, except those specially reserved by Statute to some inferior tribunal, and it can set aside the conviction , and sentence of any inferior Court, when these have been pronounced contrary to law. The headquarters of the Court are at Edinburgh, but Circuit Courts are held from time to time in provincial towns.

The Sheriff Court. Next to the Court of Justiciary, as a criminal judicatory, comes one of almost equal antiquity-that of the Sheriff or judge ordinary of the County. The Sheriff, who is also a judge in civil matters, has jurisdiction to try nearly all non-capital offences, except rape, but he cannot in any case pronounce sentence of more than two years' imprisonment.

Petty Courts. Unpaid inferior judges, magistrates in Burghs and Justices of the Peace in Counties, exercise summary criminal jurisdiction in petty cases. The power of sentence of these Courts is limited to sixty days imprisonment, except in the case of certain statutory offences, where these powers are sometimes more extensive.

\section{The Public Prosecutor.}

The general administration of the criminal law and the responsibility for criminal prosecutions are vested in the Lord Advocate, an office analogous in some respects to that of Attorney-General in England. In this work the Lord Advocate is assisted by the Solicitor-General, and by four Deputies, all members of the Bar, who are called Advocates Depute. 
All prosecutions before the Court of Justiciary are conducted by these officers. In the Sheriff Court prosecutions are conducted subject to the instructions of Crown Counsel, by a public official, who is called the Procurator Fiscal, for the county. In the Justice of Peace and Burgh Courts, prosecutions are conducted by officials specially appointed by the Justices or the Magistrates for this work. Private prosecution for criminal offences is competent in Scotland, but the injured party, who desires to prosecute, must obtain the concurrence of the public prosecutor. In practice, however, private prosecution is nearly obsolete. There has been no such prosecution before the Court of Justiciary in the present generation. It may, therefore, be affirmed generally that the whole conduct of criminal prosecution in Scotland is in the hands of public officials. The system works well, and complete confidence subsists in the adminstration of the criminal law, vexatious prosecution being unknown. The absence of complaint is indeed remarkable, in view of the extraordinary powers which the Scottish system vests in the Lord Advocate. In no country, perhaps, under popular institutions is such autocratic authority possessed by the public prosecutor. The Lord Advocate can cause whom he thinks right to be arrested or to be liberated, to be prosecuted or not to be prosecuted; he can change the venue of trial without judicial authority; and, although the Court has power to admit to bail, this power will hardly ever be exercised where the Lord Advocate intimates through his representative that in his view the ends of justice may be defeated by its being allowed. The width of these powers renders the fact all the more remarkable that only once in the present century has the action of the Lord Advocate been seriously assailed in Parliament. That happened so far back as 1805 , and the House of Commons upheld the action complained of by a very large majority.

\section{The Course of a Criminal Enquiry and Prosecution.}

Police. The maintenance of the public peace and the detection of crime are in the hands of the police force subject to such instructions as they may receive from superior authority. 
The force is a semi-municipal and semi-national one. Its general administration is in the hands of the local authorities - a representative committee in counties and the Magistrates in burghs. It is maintained by local taxation, with the aid of certain government subventions, and its officer, the Chief Constable, is appointed by the local authority. But for executive purposes the force is subject to the control of the Sheriff of the County, who is appointed by and responsible to the Crown. The Sheriff is charged with functions which are partly judicial and partly executive; he is responsible for the maintenance of order within his jurisdiction, and in cases of riotor other serious emergency he takes the control of the whole executive force, civil or military. A wide discretion is vested in the Sheriff as to the steps necessary to be taken for the prevention or detection of crime. In a recent case the House of Commons sustained his action in seizing telegrams at a post office where he suspected that the telegrams contained information that would lead to the deforcement of his officers, and the Lord Advocate stated on this occasion to the House that the Sheriff would be justified in cutting the telegraph wires if he had reason to believe that they were being used to convey criminal intelligence.

Enquiry into an Offence. Where an offence has been committed it is the duty of the police to report the matter to the Procurator Fiscal who at once proceeds with their assistance to collect evidence, and that, whether or not any person has been apprehended or is suspected. The Procurator. Fiscal may obtain a warrant to cite any person who he thinks may be able to give information likely to lead to the detection or conviction of the culprit, and to examine such person on oath, if necessary, in private. Meantime, if any person is seriously suspected, he is apprehended and brought before the Sheriff, when he is allowed, after consulting a Solicitor, to make, if he desires to do so, a declaration with reference to the charge. The Sheriff then commits the accused to prison, pending further enquiry, unless the Prosecutor consents to his liberation. If the result of the enquiry as reported by the Prose.cutor to the Sheriff is to disclose a prima facie case against 
the prisoner, the Sheriff grants a further warrant committing the accused "until liberated in due course of law," or, in other words, subject to the orders of the Lord Advocate or his Depute as to detention, liberation and trial. When, however, the case is a trifling, one the matter may, on the motion of the Prosecutor, be disposed of summarily by the Sheriff or by some other magistrate. In all other cases, the Procurator Fiscal, on completing his enquiry, or before doing so, if he desires further instruction, transmits the papers to the Crown Agent in Edinburgh by whom they are submitted to Crown Counsel, i. e., to one of the Lord Advocate's Deputes. It then rests with Crown Counsel to decide what further steps are to be taken. He may order certain further enquiries or he may decide to take no further proceedings and order the accused to be liberated, or, if the case be one of difficulty, he may refer to the Solicitor-General or the Lord Advocate for instructions, or he may at once order a prosecution, in which case he has to determine whether the accused shall be tried summarily by the Sheriff without a jury, or by the Sheriff with a jury, or by the Court of Justiciary. If the order be for summary trial, the case is disposed of within a few days (where the accused is in jail generally within six days) of the papers being retransmitted to the Procurator Fiscal. Whatever be the mode of trial decided upon, no accused person can be detained in jail more than one hundred and ten days without being brought to trial, unless the Prosecutor can satisfy the Court of Justiciary of a special cause for the delay. The accused, too, may, at any time after commitment, apply for liberation on bail, which may be allowed or refused by the Sheriff subject to a summary appeal to the High Court of Justice ; but, as above explained, liberation on bail will rarely be granted where the Crown authorities oppose it. All untried prisoners and accused persons are under the protection of the Court of Justiciary. This was exemplified in a recent case where a person was accused of forging a number of alleged historical manuscripts and autographs, some of which had been purchased by a munificent citizen of New York and presented to that city. On the application of the 
accused, the Court interdicted an Edinburgh newspaper from commenting upon the alleged forgeries, as being a course calculated to prejudice the trial of the accused.

When it has been decided that a prisoner shall be tried before the Court of Justiciary it is for Crown Counsel to determine where the trial shall take place, whether at Edinburgh, or in some other town before the Court in Circuit. Not less than sixteen clear days before trial, the accused is served with a copy of the indictment, setting forth the charge against him, and containing a list of the witnesses for the Crown and of any productions which are to be used in evidence against him. He is also entitled, if he desire it, to have access to a list of the Jury panel, from which the Jury to try him has to be balloted for.

The course of the criminal enquiry and prosecution has thus been traced from the discovery of the offence to the commencement of the trial. It will be observed as a feature of the system that the whole responsibility for and conduct of the enquiry and prosecution, are in the hands of the public prosecutor. There is no magisterial enquiry, no coroner's inquest in the case of suspected murder, and there is no Grand Jury. The criminal court is regarded as the only place for public enquiry into crime, and the duty of bringing the accused there and arraigning him rests entirely with the public prosecutor. The system is undoubtedly an excellent one for the detection and punishment of crime. It secures the aid of the highest legal intelligence in the country in this work; it provides for local -enquiry by officials possessed of local knowledge with effective control from headquarters ; the ends of justice are not defeated by the premature disclosure of the information in the hands of the authorities, whilst information is much more freely given to them by members of the public than if the preliminary enquiries were conducted in public. On the other hand, the system is theoretically weak on the side of personal liberty. It places in the hands of the public prosecutor powers which might be greatly abused by arbitrary detention in prison, by vexatious prosecution or by shielding offenders. The system, indeed, is one which could not be worked with 
satisfaction, where the authorities lay under any suspicion of venality, partisanship, or private vindictiveness. It is because no such suspicions have ever been entertained in Scotland that the system gives such general satisfaction and works so. smoothly. This is no doubt due in great measure to the fact that the Lord Advocate is always a man who has risen by his own ability to the head of the great profession of the bar, a position which no attainments can command without character behind them. The Lord Advocate is a political as well as a legal officer. He comes in and goes out with the government of his party. But, however keen he may be as a politician, as an administrator of the criminal law the Lord Advocate knows no politics, and, what is nearly as important, he is never suspected of knowing them. Whether the government be liberal or conservative, complete confidence in the impartial administration of the criminal law without respect of party or persons has always prevailed, and in any question of criminal administration the Lord Advocate has generally no stauncher supporter in the House of Commons than his predecessor in office. Were the standard of public life lower, and the traditions which surround this high office less honorable, the Scottish system is one which could not be maintained without very considerable modifications, at all events, under a democratic government.

\section{The TRIAL.}

Agent and Counsel. In the preparation of his defence the accused is entitled to the services of an agent, and at the trial to those of a counsel. So far back as 1587 this right was secured to all accused persons by Statute. A certain number of young solicitors and junior counsel are put upon a rota as: agents and counsel for the poor, and these are bound to attend to the interests of all accused persons who are unable to pay for legal assistance. In the accidental absence-of counsel for the poor, the Court may direct any other counsel to undertake the defence, and on one or two occasions, where no other advocate was present, they have ordered the Sheriff of the County to defend the accused. Counsel and Agents for the poor receive no remuneration. It has sometimes been sug- 
gested that they should receive a small remuneration from the public funds. But to this it has been objected that their services, like those of the jury, are a part of public duty, and that the defence of the poor without reward is best in keeping with the honorable traditions of the profession. As above mentioned the indictment contains a list of the Crown witnesses, and the prisoner's agent has, therefore, an opportunity of examining them beforehand. On the other hand, the accused must give the Prosecutor three days' notice of the witnesses to be called for the defence, and he must also give notice of any special defence, such as "Alibi" or Insanity at the date of the offence.

Insanity. Here it may be mentioned that insanity at the date of trial is a bar to trial, and the accused, if his insanity is established to the satisfaction of the presiding judge, is ordered to be detained during Her Majesty's pleasure. If the accused, though sufficiently recovered to plead and to be put upon trial, is found by the Jury to have been insane when the offence was committed, a similar order is made. Mental weakness, not so great as to infer irresponsibility, may reduce what appeared to be murder to culpable homicide (anglicé " manslaughter.") Drunkenness does not excuse, but, where motive is an element, drunkenness may be founded upon by the accused as excluding the inference of corrupt or malicious intent which might otherwise be deduced from his conduct. Delirium tremens is regarded as a form not of drunkenness but of insanity, and, where a crime is found to have been committed by a person in this state, the same order is pronounced as in a case of insanity.

The Jury. The jury in all criminal trials numbers fifteen, of whom ten are common jurors, five special jurors, the latter men possessed of a certain amount of means and presumably belonging to the better informed section of the community. The jury for each trial is chosen by ballot from a list containing at least thirty names. The Crown and each accused person have five peremptory challenges, i. e., challenges without reason stated-three of common and two of special jurors-and further challenges may be allowed on 
cause shown. Jury challenging, however, is a feature which does not bulk largely in Scottish criminal procedure. The Crown very rarely challenges. The accused does not challenge a juror once in ten trials ; indeed, very often by consent of all parties and for the general convenience of jurors, the same jury hears three or four cases in succession without a fresh ballot being taken. So rarely are the peremptory challenges exhausted that the occasion very seldom arises for the Court to determine what is a reasonable cause of challenge. The cause must always be one special and personal to the juryman, not one applicable to a large section of the community. Such a ground, for example, as that the juryman had seen an account of the crime in the papers would not be listened to.

Conduct of Trial. No opening statement is made by the Counsel on either side. The order of procedure, after the jury has been impanelled, is as follows: (I) The Clerk of Court informs the jury what is the charge; (2) Evidence for the Crown led; (3) Evidence for the defence led; (4) Speech for the Crown; (5) Speech for the defence; (6) Judge sums up ; (7) Jury retire if they desire to do so; (8) Verdict ; (9) Sentence or liberation. Where the trial extends over more than one day the jury is not locked up all night, except in capital cases, and, in any other case, where, from special circumstances, the Court thinks that it would be desirable.

Witnesses. The accused cannot give evidence on his own behalf or be interrogated by the prosecutor or the judge. Nor can the spouse of an accused person be examined for or against him, unless the case be one of assault by one spouse upon the other. A proposal to alter these rules and to make the accused or the spouse "competent but not compellable" witnesses has been approved of by the Scottish bar, and Parliament may, perhaps, soon deal with the matter. Witnesses not yet examined are excluded from the Court. The oath is administered not as in England by the Clerk or Registrar of Court but by the presiding Judge. The Testament is not used, but the formula is a very solemn one, viz.: "I swear by Almighty God, and, as I shall answer to God at the Great 
Day of Judgment, that I will tell the truth, the whole truth, and nothing but the truth."

Verdict. The jury return their verdict by a majority. Three verdicts are allowable_- "Guilty," "Not Guilty" and "Not Proven." The origin of the two different verdicts of acquittal is accidental. At one time they were used indiscriminately, but gradually the practice was adopted of discriminating between their use according as the jury were satisfied, on the one hand, that there was no evidence against the accused, or that his innocence was demonstrated; or, on the other hand, regarded the evidence as incriminatory but not sufficient to make it safe to convict. It is sometimes argued against this practice that the accused is entitled to be declared "Not Guilty," where there is not conclusive evidence of his guilt. On the other hand, it is doubtless a great advantage to an innocent man to be able to obtain a verdict which clears his character of all reflection, and this cannot be done where there is only one verdict of acquittal alike for the man who, for example, conclusively proves an "alibi," and for the man about whose guilt there is no moral doubt, although the legal evidence is barely sufficient. The existence of the two verdicts of acquittal is, perhaps, not unfavorable to the accused, for sometimes a juror will assent to a verdict of "Not Proven," who is morally so satisfied of the prisoner's guilt that he would have scruples about agreeing to a verdict of "Not Guilty."

The verdict is final; there is no appeal against it. The only procedure at all of the nature of an appeal in a trial in the Court of Justiciary is where a difficult question of law arises; in such an event the presiding Judge may "certify" the case for the decision of the full bench of the Court. Whatever be the verdict, the accused person cannot be tried again for the same offence. According to an old Scot expression, he has "tholed an Assize ;" and that plea, if made good in fact, is an absolute bar to further prosecution.

The Sentence.

The Death Penalty. At one time a number of crimes were 
capital offences in Scotland, and, although it had long been the practice for the prosecutor to "restrict the pains of law" in all cases, except murder, down to 1887 , a number of offences, such as rape, robbery with violence, incest and wilful preraising, were nominally capital. There has been no execution in Scotland, however, since early in the century, for anything short of murder, and under an Act passed in 1887, it was provided that no offences should becapital except murder, murderous assault, treason and rebellion. On a conviction of murder (and the law of Scotland knows of no degrees in murder) the judge must pass sentence of death. A date for execution is fixed by the sentence, generally about three weeks being the interval allowed. The prerogative of mercy then rests with the Crown, acting on the advice of the Secretary for Scotland, who gets a report from the presiding Judge. Every capital case is thus reconsidered by the Sovereign, acting through her Minister, and with the Judge and any other jurists who may be called in as assessors, and, also, if necessary, with the advice of medical experts. The enquiry is generally concluded, and a final decision arrived at before the date fixed for execution, so that an execution is rarely postponed. Fortunately, there has been no execution in Scotland during the present reign, where the legal or the public conscience has been troubled with doubts as to the justice of the verdict, or where facts have subsequently transpired which raised any such doubts.

Other Punishments. In all cases except murder and certain statutory offences for which a special sentence by way of fine or imprisonment has been provided by legislation, the judge has a discretion in regard to the sentence which cannot be questioned. As above indicated, however, an inferior judge, trying a case summarily, cannot award more than sixty days, and no inferior judge can award more than two years' imprisonment in any case. A judge of the Supreme Court may award any sentence he thinks necessary, from an admonition to penal servitude for life. It is felt by many to be a defect in the system that it leaves such a wide discretion in the hands of a single individual, and it is certainly unfortunate that, under this 
system, sentences must, to a certain extent, depend upon the idiosyncrasy of the judge. The only corrective is the Crown's prerogative of mercy, which is occasionally exercised when a sentence is deemed exceptionally harsh. The ordinary punishments inflicted by the Court of Justiciary for crimes are imprisonment, and for the more serious crimes penal servitude, the latter having taken the place of banishment to a parol settlement beyond seas. Imprisonment cannot be awarded for a longer term than two years, or penal servitude for a shorter term than three years. The prisoner is kept in solitary confinement, gets low diet, and works alone at some sedentary task; penal servants work in gangs and get harder work and more food than prisoners, but every penal servant has to do a year of solitary imprisonment as the first part of his term. The period of penal servitude is shortened by three months per annum for good conduct, and, when the period so shortened has expired, the penal servant is liberated upon " ticket of leave," under which he has to report himself periodically. All very long sentences are periodically enquired into and reconsidered by the government. Fines may be inflicted by the court in addition to or in place of imprisonment or penal servitude; prisoners may also be sentenced to be kept under police supervision for a certain number of years after expiry of their sentences; juvenile offenders may be birched, or, if incorrigible, may be ordered to be detained in a reformatory for a term of years. The infliction of corporal punishment upon adults is obsolete, and has not, as in England, been revived by Statute.

The population of Scotland, according to the Census of I891, was $4,025,647$. The average number per annum of convictions for murder is two; of executions, one. The average number of sentences of penal servitude is one hundred and twelve; average term of such sentence, six years. The average number of sentences of imprisonment (exclusive of petty police cases disposed of summarily by unpaid magistrates) 1,589 ; average term, six months. The average annual number of trials is 2,068 , with the following average results: Convicted, I,816; found "Not Guilty," 71 ; " Not Proven," I 59 ; outlawed for non-appearance, 17 ; found insane 
and unfit for trial, 3 ; found insane when alleged offence committed, 2. A very large proportion of the crime in Scotland, probably more than one-half of the serious crime, is committed by persons of Irish extraction.

Such in brief outline is the system of Criminal Administration in Scotland. The system is one which has grown with the history and progress of the country and gradually adapted itself to the changing requirements of modern life. Like the British Constitution itself, it contains some admirable provisions which may afford useful suggestions for other countries, but it is not such a system as any one would have evolved a priori and it could not be transplanted elsewhere in its entirety with any prospect of satisfactory results. But whatever be its merits or demerits from a theoretical standpoint there can be no doubt that it admirably suits the people among whom it has been developed, and that in Scotland the criminal authorities are in the present, as they have been in the past, "a terror to evil-doers, and the praise of such as do well."

Charles Pearson. Edinburgh. 